\title{
PEMBERDAYAAN PEREMPUAN KORBAN KEKERASAN DALAM RUMAH TANGGA (KDRT) OLEH DINAS PEMBERDAYAAN PEREMPUAN, PERLINDUNGAN ANAK DAN KELUARGA BERENCANA (DP3AKB) KABUPATEN JEMBER
}

\author{
Ranny Rahmawati ${ }^{1}$, Sukidin ${ }^{1}$, Pudjo Suharso ${ }^{1}$ \\ ${ }^{1}$ Program Studi Pendidikan Ekonomi, Fakultas Keguruan dan Ilmu Pendidikan, Universitas Jember \\ e-mail: 140210301033@students.unej.ac.id
}

\begin{abstract}
Abstrak
Pernikahan menurut Islam merupakan suatu perbuatan luhur dan agung, yang bertujuan untuk membentuk keluarga sakinah mawaddah warahmah. Tujuan dari pernikahan tidak selamanya berjalan mulus, ada kalanya cobaan dan godaan hingga berujung pada tindak kekerasan yang dilakukan suami/istri. DP3AKB Kabupaten Jember merupakan perpanjangan tangan dari pemerintah yang melakukan program pemberdayaan perempuan kepada korban KDRT. Pelaksanaan program pemberdayaan DP3AKB Kabupaten Jember yaitu dengan memberikan pelatihan-pelatihan kepada korban KDRT guna meningkatkan keahlian atau kemampuan mereka dalam bidang tata boga, tata rias dan menjahit. Tujuan penelitian ini yaitu mampu menjelaskan pemberdayaan perempuan korban KDRT yang dilakukan DP3AKB Kabupaten Jember dan peran pemberdayaan perempuan dalam perekonomian rumah tangga. Jenis penelitian yang digunakan adalah deskriptif kualitatif. Adapun tempat penelitian dilakukan pada DP3AKB Kabupaten Jember. Metode penentuan subyek penelitian yaitu purposive sampling dan rekomendasi. Informan utama dalam penelitian ini terdiri dari 3 sasaran yaitu pendamping sebanyak 3 orang, karyawan bidang Pemberdayaan Perempuan dan Perlindungan Anak (P3A) DP3AKB Kabupaten Jember sebanyak 1 orang dan perempuan korban KDRT (kelas ekonomi menengah kebawah dan telah mengikuti pelatihan) sebanyak 4 orang. Informan tambahan dalam penelitian ini yaitu keluarga informan inti korban KDRT sebanyak 3 orang. Teknik pengumpulan data menggunakan metode observasi partisipasi, wawancara mendalam, dan dokumentasi. Analisis data menggunakan model Miles and Huberman yaitu reduksi data, penyajian data dan conclusion drawing/ verification. Berdasarkan analisis data bahwa pemberdayaan perempuan terwujud melalui dua kegiatan yaitu pendampingan (sosialisasi, pemeriksaan kesehatan, klasifikasi masalah, pendampingan hingga pemantauan/monitoring) dan usaha kesejahteraan sosial (pelatihan tata boga, tata rias/salon dan menjahit). Peran pemberdayaan perempuan dalam perekonomian rumah tangga yaitu cukup signifikan. Hal ini terbukti dari pekerjaan yang mereka jalani mampu menghasilkan membantu suami dalam memenuhi kebutuhan keluarganya. Pekerjaan tersebut antara lain membuat kue, penjahit dan lain sebagainya.
\end{abstract}

Kata Kunci: Pemberdayaan Perempuan, Korban KDRT

\section{PENDAHULUAN}

Pernikahan menurut Islam merupakan suatu perbuatan luhur dan agung, yang bertujuan untuk membentuk keluarga sakinah mawaddah warahmah. Tujuan dari pernikahan tidak selamanya berjalan mulus, ada kalanya cobaan dan godaan datang hingga menjerumuskan suami/istri ke dalam keadaan yang tidak diharapkan. Keadaan seperti ini yang menimbulkan perselisihan terus menerus hingga berujung pada tindak kekerasan yang dilakukan suami/istri. Kekerasan merupakan suatu masalah yang sering kali terjadi di seluruh belahan dunia, tanpa terkecuali Indonesia. Kekerasan yang terjadi di masyarakat cenderung dialami oleh perempuan.

Berlakunya Undang-undang No. 23 Tahun 2004 tentang Penghapusan Kekerasan Dalam Rumah Tangga, perubahan pola pikir masyarakat tentang kekerasan dalam rumah tangga yang awalnya menjadi urusan suami dan istri, kini menjadi urusan publik. Keluarga dan masyarakat dapat ikut serta dalam mencegah dan mengawasi apabila terjadi kekerasan dalam rumah tangga. Undang-undang No. 23 Tahun 2004 merupakan salah satu bentuk perlindungan yang diberikan pemerintah terhadap korban KDRT.

DP3AKB Kabupaten Jember merupakan perpanjangan tangan dari pemerintah yang berada dibawah naungan bupati, sehingga bupati bertanggung jawab secara langsung terhadap program-program yang ada di DP3AKB. Salah satu peran yang dilakukan DP3AKB Kabupaten Jember dalam mengatasi korban KDRT adalah pemberdayaan perempuan korban KDRT. Program tersebut merupakan salah satu keterlibatan pemerintah 
dalam mengatasi dan mengurangi permasalahan Kekerasan Dalam Rumah Tangga (KDRT), karena secara umum korban Kekerasan Dalam Rumah Tangga adalah perempuan sebagai istri.

Pemberdayaan berasal dari kata dasar "daya" yang berarti kekuatan atau kemampuan, maka pemberdayaaan dapat dimaknai sebagai suatu proses menuju berdaya atau proses untuk memperoleh daya atau proses pemberian daya dari pihak yang memiliki daya kepada pihak yang kurang atau belum berdaya (Sulistiyani, 2004). Konsep pemberdayaan terdapat dua konteks. Pertama, pemberdayaan pada proses pembuatan keputusan dengan menekankan pada pentingnya peran perempuan. Kedua, pemberdayaan berkaitan dengan hubungan antara pemberdayaan perempuan dan akibatnya pada laki-laki (Zakiyah, 2010).

Ada beberapa kegiatan dalam pemberdayaan seperti pendampingan (menjadi "mediator" terutama dalam mendampingi anggota dari yang tidak tahu menjadi tahu dan dari yang tidak bisa menjadi bisa) dan usaha kesejahteraan sosial (kegiatan secara berkelanjutan dan mandiri melayani masyarakat) (Nadhir, 2009). Peran ganda perempuan dibagi menjadi dua, yaitu peran domestik yaitu bertugas mengurus rumah tangga dan peran publik yang bertugas di luar rumah untuk berkerja memenuhi kebutuhan hidup keluarga (Ollenburger dan More, 1996). Menurut Barbara (1980) dalam Susanti (2013:48) kontribusi pendapatan yang dihasilkan perempuan untuk menambah penghasilan keluarga dan membantu mengentaskan keluarga dari kemiskinan.

Hasil observasi awal diketahui bahwa korban kekerasan dalam rumah tangga yaitu mayoritas disebabkan faktor ekonomi dalam keluarga yang pas-pasan, bahkan cenderung kurang untuk memenuhi kebutuhan sehari-hari. Permasalahan inilah yang sering kali menjadi akar permasalahan dari kasus KDRT. Bentuk kasus KDRT dalam bentuk kekerasan fisik (memukul, menendang, menampar), psikis (menghina dengan perkataan yang menyakiti hati), seksual (pelecehan seksual, pemerkosaan/pemaksaan dalam berhubungan suami istri), penelantaran (tidak menafkahi secara sewajarnya/memberikan batasan nafkah), dan lain-lain (berkata kasar dan tidak senonoh).

Pelaksanaan program pemberdayaan DP3AKB Kabupaten Jember yaitu dengan memberikan pelatihan-pelatihan kepada korban KDRT guna meningkatkan keahlian atau kemampuan mereka dalam bidang tata boga, tata rias dan menjahit. Pelatihan yang diberikan bertujuan untuk meningkatkan pendapatan dan perekonomian rumah tangga mereka yang semula kurang dalam memenuhi kebutuhan sehari-hari. Faktor ekonomi menjadi penyebab utama terjadinya KDRT.

Kegiatan pemberdayaan mampu mengembangkan potensi sehingga mampu meningkatkan perekonomian keluarga dan kemandirian usaha (Roza Linda, 2015). Penelitan lain yang sejalan dengan ini yaitu Rr. Niken Sitoresmi dan Siti Amanah (2012) yang mengungkapkan dalam pemdapingan korban kekerasan salah satunya dengan mengadakan pelatihan-pelatihan tata boga. Pemberdayaan perempuan dalam hal ini pelatihan pemberdayaan perempuan (tata boga, make up, hingga menjahit) diharapkan mampu meningkatkan perekonomian keluarga serta mengatasi akar permasalahan dari tindak kekerasan dalam rumah tangga.

Berdasarkan pemaparan di atas, maka peneliti bermaksud mengadakan penelitian yang bertujuan untuk menjelaskan pemberdayaan perempuan korban KDRT yang dilakukan DP3AKB Kabupaten Jember dan peran pemberdayaan perempuan dalam perekonomian rumah tangga.

\section{METODE}

Penelitian ini dilakukan dengan metode deskriptif kualitatif. Adapun metode penentuan lokasi penelitian menggunakan purposive area dan penentuan sampel menggunakan purposive sampling dan rekomendasi, yakni informan utama dalam penelitian ini terdiri dari 3 sasaran yaitu pendamping sebanyak 3 orang, karyawan bidang Pemberdayaan Perempuan dan Perlindungan Anak (P3A) DP3AKB Kabupaten Jember sebanyak 1 orang dan perempuan korban KDRT (kelas ekonomi menengah kebawah dan telah mengikuti pelatihan) sebanyak 4 orang. Informan tambahan dalam penelitian ini yaitu keluarga informan inti korban KDRT sebanyak 3 orang. Metode pengumpulan data menggunakan Teknik pengumpulan data menggunakan metode observasi partisipasi, wawancara mendalam, dan dokumentasi. Analisis data menggunakan model Miles and Huberman yaitu Data Reduction (Reduksi Data), Data Display (Penyajian Data), dan Conclusion Drawing/Verification.

\section{HASIL DAN PEMBAHASAN Hasil Penelitian}


Kegiatan pemberdayaan perempuan melibatkan proses peningkatan dan pengembangan daya/ kemampuan baik pengetahuan, keterampilan hingga kekuasaan yang dapat mempengaruhi hidupnya lebih baik dan mandiri. Pemberdayaan perempuan yang dilakukan oleh DP3AKB untuk membuat korban KDRT lebih berdaya dan melupakan masalah kekerasan yang menimpanya dengan memiliki kesibukan. Korban KDRT tidak diharuskan untuk mengikuti pelatihan, tetapi keputusan keikutsertaan diserahkan sepenuhnya kepada korban KDRT. Berdasarkan hasil wawancara dengan beberapa informan diketahui bahwa pemberdayaan perempuan yang dilakukan DP3AKB dilakukan dengan beberapa kegiatan seperti pendampingan dan usaha kesejahteraan sosial.

Pendampingan yang dilakukan oleh DP3AKB kepada masyarakat dan korban KDRT ada beberapa tahapan yaitu pencegahan dan penanggulangan. Pendampingan pencegahan yang dilakukan kepada masyarakat dan korban KDRT dilakukan DP3AKB yaitu melalui sosialisasi tentang pernikahan dini hingga perlindungan ibu dan anak. Sosialisasi tersebut selain memberikan gambaran tentang penyebab KDRT salah satunya pernikahan dini, juga memberikan informasi bahwa DP3AKB bertugas membantu mereka jika terjadi KDRT dan melindungi mereka dengan bantuan beberapa mitra DP3AKB.

Sedangkan pendampingan yang dilakukan untuk ibu atau anak yang telah menjadi korban KDRT yaitu pemeriksaan kesehatan, klasifikasi masalah, pendampingan hingga pemantauan/monitoring. Tahapan tersebut bertujuan untuk menyembuhkan trauma yang mendalam korban KDRT, dan menyelesaikan kasus KDRT yang menimpa beliau. Cara penyelesaian dilakukan yaitu dengan memulihkan rasa percaya diri korban KDRT dan memberikan ketenangan. Jika dirasa sudah lebih baik langkah selanjutnya yaitu dengan musyawarah antara istri, suami dan DP3AKB selaku penengah masalah. Hasil dari musyawarah akan menentukan langkah DP3AKB selanjutnya, seperti membantu membawa kasus ke meja hijau jika kasus dirasa tidak bisa diatasi dengan musyawarah. Sedangkan pemantauan/monitoring jika dirasa masalah KDRT mampu diatasi dengan bermusyawarah, tujuannya supaya kasus KDRT tidak terjadi lagi.

Korban KDRT yang sudah mulai membaik akan diarahkan untuk mengikuti usaha kesejahteraan sosial yang diadakan DP3AKB Kabupaten Jember. Kegiatan usaha secara berkelanjutan dan mandiri dalam melayani masyarakat yaitu dengan cara DP3AKB mengelola dalam pembiayaan program seperti pelatihan-pelatihan. Usaha yang dilakukan DP3AKB yaitu dengan menyelenggarakan pelatihan kepada korban KDRT dengan tujuan untuk memberikan kesibukan, selain itu juga supaya para korban mampu lebih mandiri dan mendapatkan penghasilan setelah mengikuti pelatihan tersebut. Pelatihan yang diselenggarakan DP3AKB ini meliputi pelatihan tata boga, menjahit dan tata rias. Lebih jelasnya tentang pelatihan yang diselenggarakan DP3AKB sebagai berikut:

Tabel 1. Bentuk Pelatihan yang Diselenggarakan DP3AKB

\begin{tabular}{lllll}
\hline No. & Bentuk Pelatihan & $\begin{array}{c}\text { Lama } \\
\text { Pelatihan }\end{array}$ & $\begin{array}{r}\text { Jumlah } \\
\text { Peserta }\end{array}$ & Pendamping (LKP) \\
\hline 1. & Menjahit & 20 hari & 15 orang & LKP Isti \\
\hline 2. & Tata Boga & 2 hari & 14 orang & Bogasari \\
\hline 3. & Tata Rias/Salon & 10 hari & 15 orang & LKP Piesca dan Salon Silvi \\
\hline
\end{tabular}

\section{Sumber: Data primer (diolah)}

Pendamping dalam pelatihan melibatkan secara langsung pelatih dari beberapa LKP yang telah memiliki sertifikat keahlian, sehingga materi yang diberikan dan dipraktekkan tidak diragukan lagi. Pendampingan dilakukan oleh DP3AKB selaku pelaksana kegiatan serta dari pihak LKP selaku pendamping pelatihan/instruktur. Bentuk pelatihan tata boga, tata rias/salon dan menjahit disesuaikan dengan kemampuan perempuan secara umum. Harapan setelah pelatihan selesai korban KDRT mampu mengembangkan kemampuan mereka dengan menjalankan usaha guna membantu untuk pemenuhan kebutuhan keluarga mereka.

Peran pemberdayaan perempuan dalam perekonomian rumah tangga dalam hal ini yaitu berkaitan dengan kemanfaatan penghasilan perempuan bagi pemenuhan kebutuhan rumah tangga. Pemberdayaan perempuan yang dilakukan DP3AKB berdampak pada peningkatan kemampuan yang dimiliki peserta pelatihan 
yang kemudian digunakan untuk menjalankan usaha. Berbicara mengenai ekonomi adalah juga berbicara mengenai perempuan, sebab kenyataannya perempuan memiliki beberapa peran. Salah satu peran perempuan dalam ekonomi yaitu peran publik dimana perempuan mempunyai peran untuk memperoleh penghasilan yang digunakan untuk memenuhi kebutuhan keluarganya. Berikut ini tabel yang menunjukkan usaha yang dijalankan korban KDRT dengan memanfaatkan ilmu yang mereka dapatkan dari pelatihan.

Tabel 2. Pekerjaan Korban KDRT

\begin{tabular}{lllll}
\hline No. & Nama & Sebelum Pelatihan & \multicolumn{1}{c}{ Sesudah Pelatihan } & \multicolumn{1}{c}{ Penghasilan } \\
\hline 1. & Ibu Ulum & Kader Posyandu & Penjahit & Rp 60.000 - Rp90.000/hari \\
\hline 2. & Ibu Suryati & Ibu Rumah Tangga & Pembuat Kue Bakery & Rp60.000 - Rp75.000 /hari \\
\hline 3. & Ibu Oon & Kader Posyandu & $\begin{array}{l}\text { Tukang Salon dan Kader } \\
\text { Posyandu }\end{array}$ & Rp20.000 - Rp40.000 /hari \\
\hline
\end{tabular}

\section{Sumber: Data primer (diolah)}

Keberdayaan wanita di bidang ekonomi adalah salah satu indikator meningkatnya kesejahteraan dan kemandirian yang ditandai dengan mampu mendapatkan penghasilan melalui usaha yang dilakukannya. Kemandirian ini terlihat dari peserta pelatihan yang mampu menjalankan usahanya dengan memanfaatkan ilmu yang mereka peroleh ketika pelatihan. Peserta pelatihan tidak semuanya dapat menjalankan usaha sesuai dengan ilmu yang mereka peroleh dari pelatihan. Berikut ini tabel yang menunjukkan jumlah peserta yang gagal menjalankan usaha dengan memanfaatkan ilmu yang mereka dapatkan dari pelatihan.

Tabel 3. Jumlah Peserta yang Gagal Menjalankan Usaha

\begin{tabular}{clcc}
\hline No. & Bentuk Pelatihan & Total Jumlah Peserta & Jumlah Peserta yang Gagal \\
\hline 1. & Menjahit & 15 orang & 1 orang \\
\hline 2. & Tata Boga & 14 orang & 8 orang \\
\hline 3. & Tata Rias/Salon & 15 orang & 12 orang \\
\hline
\end{tabular}

\section{Sumber: Data primer (diolah)}

Korban KDRT yang mengikuti pelatihan tidak selamanya mampu mengaplikasikan ilmu yang mereka peroleh dengan baik. Penyebab utama pelatihan tata rias/salon paling banyak peserta yang gagal menjalankan usaha yaitu faktor permodalan. Modal yang dibutuhkan untuk menjalankan usaha salon yang cukup besar. Peralatan yang beraneka ragam ditambah beberapa cream kecantikan dan pewarna rambut, belum lagi tempat untuk menjalankan usaha salon. Hal ini yang membuat peserta pelatihan tata rias/salon berfikir dua kali untuk menjalankan usaha salon.

\section{Pembahasan}

Hasil analisis data telah dijabarkan di atas diketahui bahwa pemberdayaan perempuan yang dilakukan DP3AKB kepada korban KDRT yaitu dengan mengadakan beberapa pelatihan seperti pelatihan tata boga, tata rias/salon dan menjahit. Pemberdayaan dilakukan dengan cara mengadakan pelatihan kepada korban KDRT, sehingga para korban KDRT mendapat bekal keterampilan, dan pengetahuan mengenai bidang tata boga, tata rias/salon dan menjahit. Sebagaimana pendapat Sulistiyani (2004: 77) yang berpendapat bahwa pemberdayaan yaitu sebuah proses menuju berdaya atau proses untuk memperoleh daya atau proses pemberian daya dari pihak yang memiliki daya kepada pihak yang kurang atau belum berdaya.

Peningkatan kemampuan baik pengetahuan, keterampilan dapat mempengaruhi hidupnya lebih baik dan mandiri. Kemandirian perempuan ini bukan berarti lebih unggul dari laki-laki, akan tetapi agar perempuan memiliki nilai lebih dimata laki-laki sehingga tidak dipandang sebelah mata. Sebagaimana pendapat Moser (1993:37-54) bahwa pemberdayaan bukan bermaksud menciptakan perempuan yang lebih unggul dari kaum 
laki-laki, namun lebih berupaya untuk mengidentifikasi kekuasaan bukan sekedar dominasi laki-laki terhadap perempuan, melainkan dalam kerangka kapasitas perempuan untuk mengingkatkan kemandirian. Kemandirian dalam hal ini lebih kepada kontribusi penghasilan yang dilakukan korban KDRT yang berimbas kepada kesejahteraan sosial keluarga, otoritas pengambilan keputusan dan manajemen keluarga.

Peran perempuan dalam mendapatkan penghasilan yaitu salah satu bentuk terlaksananya peran publik, dimana perempuan berperan untuk bekerja di luar rumah dan mempunyai penghasilan untuk memenuhi kebutuhan keluarganya. Sejalan dengan pendapat Ollenburger dan More (1996:7) peran ganda perempuan dibagi menjadi dua: peran domestik yaitu perempuan bertugas mengurus rumah tangga dan peran publik yaitu perempuan bertugas di luar rumah untuk berkerja memenuhi kebutuhan hidup keluarga. Peran publik yang mereka lakukan yaitu dengan menjalankan usaha dengan memanfaatkan kemampuannya yang didapatkan dari pelatihan (tata boga, tata rias/salon dan menjahit). Penghasilan yang mereka dapatkan digunakan untuk memenuhi kebutuhan keluarganya dan membantu suami mereka dalam mencari nafkah.

Namun dari beberapa peserta pelatihan yang telah mengikuti pelatihan hanya beberapa saja yang mampu menjalankan dan mengembangkan usaha mereka. Keputusan untuk menjalankan usaha tergantung pada kemampuan dan kemauan mereka masing-masing. Kontribusi yang mereka berikan telah sedikit merubah tingkat kekuasaan di kehidupan keluarga mereka. Awalnya dalam pengeluaran keluarga dibatasi oleh suami terutama untuk pengeluaran arisan, dan pengeluaran lainnya. Kini dengan adanya kontribusi pendapatan dari perempuan dapat merubah hal tersebut, pengeluaran seperti arisan tidak dipermasalahkan karena adanya hak istri dalam penggunaan uang. Hal ini menunjukkan bahwa terdapat perubahan dalam otoritas pengambilan keputusan yang semula husband dominat decision (keputusan suami lebih dominan) menjadi syncratic decision (keputusan suami dan istri seimbang). Berbeda halnya dengan Ibu Suryati, beliau telah berpisah dengan suaminya dan tidak dinafkahi lagi. Artinya beliau dan anaknya telah ditelantarkan oleh mantan suaminya. Perubahan otoritas pengambilan keputusan yang dialami Ibu Suryati terjadi karena kondisi yang memaksa mereka melakukan seperti itu karena telah hilang fungsi seorang suami dalam rumah tangga.

\section{PENUTUP}

Berdasarkan hasil penelitian dan pembahasan mengenai pemberdayaan perempuan yang dilakukan DP3AKB Kabupaten Jember dapat disimpulkan bahwa Pemberdayaan perempuan diwujudkan melalui pendampingan (sosialisasi, pemeriksaan kesehatan, klasifikasi masalah, pendampingan hingga pemantauan/monitoring) dan usaha kesejahteraan sosial (pelatihan tata boga, tata rias/salon dan menjahit). Hasil dari pemberdayaan perempuan yang dilakukan DP3AKB Kabupaten Jember membuat korban KDRT lebih mandiri dari sebelumnya, hal ini terbukti dari tingkat kesejahteraan sosial keluarga meningkat, otoritas pengambilan keputusan dan manajemen keluarga yang melibatkan pihak istri mereka. Sedangkan korban KDRT yang ditinggal suami, mereka menjadi mandiri karena kondisi yang memaksa mereka untuk mengambil alih peran suami dalam keluarga. Namun ada beberapa peserta pelatihan yang gagal dalam mengaplikasikan ilmu mereka. Peserta yang paling banyak gagal yaitu berasal dari pelatihan tata rias/salon. Faktor utama yang membuat gagal yaitu permodalan. Modal yang pas-pasan membuat mereka berpikir dua kali untuk menjalankan usaha salon.

Berdasarkan kesimpulan di atas, maka penulis memberikan saran kepada DP3AKB Kabupaten Jember, DP3AKB Kabupaten Jember memikirkan terlebih dahulu tentang keefektifan, dan keefisienan dalam memberikan bantuan tersebut. Sedangkan bagi korban KDRT yang gagal dalam menjalankan usaha, sebaiknya dibantu atau memberikan rekomendasi dalam mencari pekerjaan.

\section{DAFTAR PUSTAKA}

\section{Buku}

Moser, Caroline O. N. 1993. Gender Planning and Development: Theory. Practice and Training. New York: Routledge. 
Nadhir. 2009. Memberdayakan Orang Miskin Melalui Kelompok Swadaya Masyarakat. Lamongan: Yapsem.

Ollenburger, J.C dan Moore, H. A. 1996. Sosiologi Perempuan. Jakarta: PT Rineke Cipta.

Sulistiyani, Ambar Teguh. 2004. Kemitraan dan Model-Model Pemberdayaan. Yogyakarta : Graha Ilmu.

Zakiyah. 2010. Pemberdayaan Perempuan oleh Lajnah Wanita. Jurnal Pengkajian Masalah Sosial Keagamaan, XVII.

\section{Jurnal Ilmiah}

Linda, Roza. (2015). Pemberdayaan Perempuan dalam Meningkatkan Kemandirian Usaha melalui Pelatihan Keterampilan Menyulam pada Usaha, Peningkatan Pendapatan Keluarga Sejahtera (UPPKS) Sumber Rezeki Kelurahan Tangkerang Labuai. Jurnal Perempuan, Agama dan Jender, Volume XIV, No. 2 Desember Tahun 2015 E-ISSN : 2407-1587

Sitoresmi, Rr. Niken dan Siti Amanah. (2012). Pendampingan Perempuan Korban Tindak Kekerasan oleh Pusat Pelayanan Terpadu Pemberdayaan Perempuan dan Anak (P2TP2A). Sodality: Jurnal Sosial Pedesaan, Volume: 6, No. 3 (2012) ISSN :2302-7517

Susanti, Fatimah Depi. (2013). Kontribusi Perempuan Parengge-Rengge dalam Ekonomi Keluarga. Sosial Budaya, Volume. 10, No. 01 Januari-Juni 2013. Halaman 48

\section{Sumber dari Undang-Undang}

Undang-undang Nomor 23 Tahun 2004 tentang Penghapusan Kekerasan dalam Rumah Tangga 